\title{
Ending the Digital Gender Divide. Are Coding Clubs the Solution?
}

\section{Acabar amb la bretxa digital de gènere, ¿els clubs de programació són una solució viable?}

\section{David Ramírez-Plascencia}

Rosa María Alonzo-González

University of Guadalajara (Mexico)

There is a shared lasting concern in both developed and developing countries regarding the low rates of participating women in STEM (science, technology, engineering and mathematics). In this context, one of the most frequent actions is the development of STEM and coding workshops as a way to increase the presence of women in these fields. The main object of this article is not only to provide a description of the programs that support girls into STEM, but also to make a critical analysis of their design. This research employs the content analysis approach, a technique to make replicable and valid inferences from texts. The methodology sample came from a comprehensive review of 64 programs announced online that aim to support the incorporation of girls and women into STEM, particularly Information technology. As the final outcomes will show, besides the high popularity of these programs, there are important questionings regarding
Hi ha una preocupació compartida entre països desenvolupats $i$ en vies de desenvolupament respecte a les baixes taxes de dones en àrees STEM (ciència, tecnologia, enginyeria $i$ matemàtiques). En aquest context, una de les estratègies més freqüents és el desenvolupament de tallers per aprendre a programar $i$ de cursos amb activitats relacionades amb disciplines STEM, amb la finalitat d'augmentar la presència de dones en aquestes àrees. L'objectiu principal d'aquest article no és tan sols proporcionar una descripció dels programes que donen suport a la inclusió de les nenes en la ciència, sinó també fer-ne una anàlisi crítica sobre el disseny i la implementació. Aquesta investigació utilitza la tècnica d'anàlisi de contingut, una tècnica que permet fer inferències vàlides $i$ replicables des dels textos. La mostra estadística de la metodologia prové d'una revisió exhaustiva de 64 programes anunciats en línia que tenen l'objectiu de donar su- 
their design and implementation, particularly about the effectiveness of their actions in reducing the problems associated with the digital gender divide and the inclusion of women into STEM academia and STC industry.

Key words: Digital gender divide, STEM girls, empowerment, coding clubs, gender inequality. port a la incorporació de nenes i dones en les disciplines STEM, sobretot en les tecnologies de la informació. Els resultats finals demostren que, tot i la gran popularitat d'aquests programes, se's qüestiona força pel que fa a la seva execució, especialment l'efectivitat de les seves accions per reduir la bretxa digital de gènere i la inclusió de les dones en la ciència.

Paraules clau: bretxa digital de gènere, nenes STEM, empoderament, clubs de programació, iniquitat de gènere.

$\mathrm{A}$ s the world approaches the second decade of the XXI century, about half of the global population is connected to the Internet (The Economist, 2019). This amazing technological advance has brought a galore of opportunities, tools and novel spaces of socialization. For more than 3.5 billion people, an important part of their social, economic and political activities occurs inside virtual spaces. Devices like smart phones, tablets, or laptops are no longer accessory objects, but intrinsic elements of their daily life. However, besides the advances in Internet connectivity, particularly in China, India, Africa, and Latin American countries, there are still huge barriers and glitches that must be surpassed to get a more inclusive and fair access to the digital medias: problems associated with the censorship of contents, the virtual harassment and the propagation of the hate speech across social media platforms, among others. In addition, there are still the persistent glitches linked to the lack of access to the information technologies, commonly known among scholars and international institutions as the digital divide. As a matter of fact, this concept is no longer associated exclusively with the shortage of infrastructure, or the absence of digital skills to operate the computers and to browse across the Internet; or the Manichean problem among those who are informational-rich and those who are poor, as it happened at the beginning of the new millennia (OECD, 2000; Rogers, 2001; UNESCO, 2003). Notwithstanding, the debate about how to reduce the digital divide stands pertinent and actual, not only because the other half of the global population does not have access, but for many people there are still genre, age or cultural barriers that limit their opportunities of taking advantage from these technologies. In a matter of two decades, however, not only the concept, but the analysis has also evolved. Currently, more than talking about the digital divide in particular, the 
problem is comprised in plural (Peral, Gaitán, and Ramos, 2015; OECD, 2019). The actual conception of the digital divide involves all those geographic, cultural, genre, cognitive, social and economic factors that have a direct effect in how people access the digital technologies (OECD, 2015). This is the case of the digital gender divide.

The concerns about the social and economic barriers that limit the access of women to information technologies (digital gender divide) are not new, and they certainly did not start with social media and smart phones. When personal computers spread in the 1980 decade, scholars and practitioners set the first questions about how to encourage women, particularly young girls, to approach computers, not just as users, but as active participants in the IT industry and academia (Lovegrove, 1991; Miller et al., 2000). As novel technologies such as the Internet and mobile devices arrived, the digital gender divide, far from diminished, became more complex and challenging. The problem is more intricate than just the deficient access to Internet and the development of digital skills. Those are necessary, but not sufficient conditions. In the case of women, there are several barriers that have traditionally affected them more than men: lower rates of education, the lack of digital competences, long-established gender prejudices and legal and customary discriminatory norms (Abu-Shanab and Al-Jamal, 2015; Gray, Gainous, and Wagner, 2017). In 1979, the United Nations promulgated the "Convention on the Elimination of All Forms of Discrimination against Women" (Naciones Unidas, 1979), which, in among other important statements, encouraged their state members to eradicate any form of prejudice towards women and to set the proper conditions that enables the equal access of education to women. Meanwhile, further efforts have made patent how the genre educational discrimination, particularly in the field of Information technologies (IT), has become a key global issue (Naciones Unidas, 1995; Grupo de Trabajo "Género y TIC", 2010). As Information technologies settled as one of the most important sources of wealth and a central element in people's daily life, the social disparities caused by the digital gender divide have grown, limiting the participation of women in the media and communication sector (IWMF, 2011; UNESCO, 2012; WACC, 2015) and in the IT industry, in which women represent only $24 \%$ of graduates from engineering, manufacturing and construction, and $25 \%$ in the IT field. (OECD, 2018). In addition, a recent study shows how, at international level, the ratio of women who are dedicated to academic research in the STEM fields (Science, Technology, Engineering and Mathematics) is only 28.8\% (UNESCO, 2018b).

Besides this adverse panorama, in recent years there have been important endeavors to raise the presence of women in the media and IT sectors and to reach a more equal workplace inside those corporations (Vega-Montiel and Macharia, 2019; French, Vega-Montiel, and Padovani, 2019). Concerning the promotion of the equal access to education, particularly in technology programs (one of the targets of UN sustainable development goals (4.3 and 5.B), there has been a huge irruption of courses, talks and festivals with the aim of encouraging young girls to approach STEM academic fields, mainly information technologies. Labeled under different names, "workshops" "meetings" "courses" "talks" "bootcamps" 
"sessions" "clubs" "laboratories" and so on, these programs have proliferated at a global level under the auspice of international organizations, companies, governments and universities. The purpose of this research is not only to describe these programs, but to provide a critical analysis of the opportunities and glitches of implementing these actions to promote the incorporation of women into science in general. This research starts with a review of the academic literature about genre, information technologies and education. In the subsequent section, there will be a detailed description of the methodology applied in the research, and then it will follow the results. The last part of this paper will provide a discussion about the outcomes and the conclusions of this research.

\section{INFORMATION TECHNOLOGIES, WOMEN AND EMPOWERMENT}

For more than twenty years, governments and international organizations have tried to improve women's social and economic conditions through the use of information technologies (Hafkin and Taggart, 2001; Moghadam, 2010; World Wide Web Foundation, 2014; United Nations, 2018). They have organized courses, invested in infrastructure and giving talks and conferences exposing how the Internet can empower women. While the intention remains practically the same, the technology has evolved. From desktop computers up to mobile devices, and from static websites to dynamic and interactive social platforms. That global spread and diversification of information technologies has influenced in in what way national and international organizations address the problem of the digital gender divide and the development of social programs to empower women. One of these effects is present in how these organizations have associated the concept of empowerment with information technologies. At the beginning of the new millennium, the Internet and computers were the key elements to support women empowerment (Colnodo, 2006). Successively, social media and mobile devices were incorporated into this equation (Gordon and Trammel, 2016). By the end of 2019, local and international organizations have made a special emphasis in supporting girls through the implementation of code workshops (Júnior et al., 2019; UNESCO, 2018a). While the objective has endured unaltered since decades, every new technology has been endowed with promising and disruptive potentialities. A similar belief could be appreciated regarding the concept of "empowerment".

"Empowerment" in one of the most well-known definitions, is "the mechanism by which people, organizations and communities gain mastering of their own life" (Rappaport, 1984: 3). This mechanism, however, does not operate in an isolated plain, but on the contrary, is multi-dimensional, since it occurs in diverse spaces: social, economic, psychological, and across different levels: the individual, the group and the community (Page and Czuba, 1999); empowerment cannot be unidirectional, from institutions to individuals, but on the contrary, it is a process that implies the participation and involvement of individuals in community decision-making (Zimmerman, 2000). Besides the frequent usage of 
the term empowerment (empoderamiento in Spanish and Portuguese, and émancipation in French) in official documentation and academic production, most of the evaluated literature does not provide a clear definition of the concept or give some indications of what they understand for women's empowerment, or even, how do they think the information technologies empower them. Inside this documentation, "to empower" has been associated with miscellaneous actions and goals: participation in decision making in society and to have reproductive rights (Roudi-Fahimi and Moghadam, 2003), improving self-confidence and revisiting genre stereotypes (Medeiros, 2005), and the ability to produce changes and to learn skills (Gordon and Trammel, 2016), or the access to equal social conditions (UNESCO, 2018a), a change in the laws that discriminate women (CEPAIM, 2015). This absence of clearness, as it will be observed in the result's section of this paper, is a recurrent issue in the code workshops and clubs to support girls' empowerment as well. This unclearness, of course, does not demerit the efforts or the intention of the programs but, as it will be observed further, this lack of certainty in the usage of the concept "empowerment" and the magnification of the real potentialities of the programs' final outcomes could eventually cause disenchantment among participants and practitioners.

\section{SCIENCE AND CODE AS PATHS TO EMPOWER WOMEN}

As mentioned before, there is a shared lasting concern in both developed and developing countries regarding the low rates of women participation in STEM disciplines (Science, Technology, Engineering and Mathematics) at university (Farmer, 2008; Rivest, 2015; Montgomery and Fernández-Cárdenas, 2018; UNESCO, 2019; Baumermann and Kuchlmayr, 2019). The little attendance of young women in undergraduate and graduate STEM programs, alongside with traditional stereotypes and genre discrimination, translates into a small incorporation of women into science and technology corporations (STC) as well. However, there is a renewed interest among scholars and practitioners at a global level in finding effective actions to encourage the interest of women, particularly girls and young women in STEM disciplines, and to increase the presence of women in STC corporations (Rivest, 2015; Shewmaker and Lee, 2015; Minichiello, 2018; Whynot et al., 2019). Recent literature on the topic highlights the crucial role of family and school mentors' support to keep the interest of girls in science, but at the same time, they emphasize the negative impact of traditional labels that portray science as an exclusive field for men (Rogan and de Kock, 2005; Nimmesgern, 2016; Holanda et al., 2017). They also propose the development of mentoring programs and courses to promote the enrollment and permanence of women in STEM academia and industry (Koch, Polnick, and Irby, 2014; Youance and Groleau, 2018; Nation et al., 2019). In this context, one of the most recurrent actions employed is the development of codes and robotic workshops as a way to increase the interest of science in girls (Bendiek, 2017; UNESCO, 2018c; Sanabria-Z and Romero, 2019). Besides, the organization of STEM or code workshops is not a new idea. The popularity of these projects is booming. It is practically possible to find them 
across the globe. Even the acronym STEM has been widely adopted in other languages: in German MINT (Mathematik, Informatik, Naturwissenschaft und Technik) and in French STGM (sciences, technologie, génie et mathématiques). While most of the programs center on helping girls and young girls to approach STEM as a form to empower them, the scope and actions tend to vary significantly: from a regular course of one year, to workshops of one day or even a public talk. However, as it will be possible to observe in the outcomes, while many of these programs publicize themselves as actions to promote STEM as a whole, most the time they just offer courses or materials in the field of information technologies, most precisely focusing on learning computer programming. In addition, there is still the recurrent lack of certainty, as it happened with traditional programs of this kind, when using the word "empowerment", since these programs do not establish a clear definition on this concept, and they do not make patent how these programs will, at the end, support women's empowerment.

\section{RESEARCH PROPOSAL}

The main object of this article is not only to provide a description of the programs that support girls into STEM field, but to make a critical analysis of their design. Despite the importance of this task, it is necessary to settle a careful examination on the scope and effect of these actions. As it will be possible to observe in the discussion section of the text, there are recurrent issues across these programs that should be carefully examined to improve their implementation and outcomes. Some of the issues are not new, since they were present in the first programs of this kind at the beginning of the 2000 decade: (a) a reductionist conceptualization of the term "STEM disciplines" for "Information technologies", more specific to code or robotic", (b) an overestimation of the final outcomes of these programs, (c) the utilization of the empowerment term without providing further contextualization or academic support, (d) an oversimplification of the study of scientific disciplines, (f) the proliferation of a commodified model to develop these programs and finally, (g) the imposition of an aspirational stereotype model of scientific women. These considerations do not pretend to be a direct attack on these programs but on the contrary, what this paper proposes is to set a more critical view on their design, to develop a more realistic approach to their goals.

\section{MATERIAL AND METHODS}

This research employs the content analysis approach, a technique to make replicable and valid inferences from texts (Krippendorff, 2018), with the aim to comprehend the textual meaning of the documents (Gheyle and Jacobs, 2017). This research will follow the model proposed in (Riffe, Lacy, and Fico, 2013): (a) identifying the problem and elaborate research questions, (b) specify the population and establish the sampling plans, (c) process data and interpret the results. 
The sample came from a comprehensive review of 70 programs announced online that have the aim to support the incorporation of girls and women into STEM. The Fieldwork's aim was to provide an outline of the most important characteristics of these programs, their actions and goals. Data gathered was conducted during the months of July and August of 2019, using some regionalized versions of the Google Search Engine (google.com, google.com.mx, google.com.br, google. de, google.fr, and so on) and using diverse keywords like "STEM for girls", "STEM clubs", "STEM courses", "code courses for girls", "code clubs for girls", "empowering girls with STEM", in many cases those terms were translated from English into German, Spanish or French to get a more accurate outcome from the search engine. After a careful examination, some programs with insufficient information were discharged. At the end, 64 programs were selected to conform the sample of this study. $64 \%$ of the information was obtained from primary sources (official websites) and $36 \%$ for secondary sources, predominantly news promoting the program (78\%), and academic journals (13\%) reporting final results from some courses or workshops, and the last $8 \%$ from other online sources. Descriptive statistics were used to organize the information. Data was arranged using 12 variables divided into three main categories (1) general aspects, (2) actions, and (3) goals. In the general aspects' category, 5 variables were considered: (a) opening year of the program, (b) country, (c) the public, (d) sponsor type, and (e) sponsor nationality. The next category, "actions" embraces 4 variables related with activities offered by these programs (f) main topic, (g) association with STEM fields, (h) activities offered, and (i) length. And finally, the category "goals" considered 3 variables, (j) main goal of the program, (k) goals associated with women's empowerment and, (l) the explicit use of the word "empowerment."

\section{RESULTS}

The total amount of programs considered for the present research were 64 . The analysis of variables in the general aspects' category revels a growing global interest in developing these actions to support women participation in STEM fields. $77 \%$ of the programs were created in the last five years $(2015=5 \%, 2016=8 \%$, $2017=11 \%, 2018=23 \%$ and $2019=30 \%$ ). However, in the last two years, 2018 and 2019, 34\% programs were settled. This huge growth confirms their popularity among local and international organizations. However, it is important to note that this model is not new, but on the contrary, it has been present for years, about $5 \%$ of the cases dated from 2006. Most of these programs were conducted in Mexico (25\%), United States (16\%), Spain (11\%), Germany (8\%), France (8\%), and Brazil (6\%). Most sponsors are non-governmental organizations (46.5\%) and private corporations (30.5\%), conversely, local and federal governments $(9.5 \%)$ and universities (13.5\%) have less involvement in these kinds of programs. The sponsors' nationality variable holds a symmetrical tendency in comparison to the country in where the programs were actually implemented: $22 \%$ of the sponsors are from Mexico, United States (16\%) and Spain (11\%). In this context, it is important to highlight how international organizations like the World Bank 
and big corporations like Mastercard or UBER are implementing code clubs and workshops in diverse African and Latin American countries. This provides important evidence of how global corporations are including these models into their corporate social responsibility agendas. Regarding the category number (2) "actions", most of the programs' activities (78\%) are focused on young girls (from elementary school to high school), but there are examples in where some organizations provide different courses depending on the age (19\%), from little girls up to women, they are even courses centered in helping unemployed women to find a job. The more recurrent activities offered are participating in workshops $(37 \%)$, or courses $(26 \%)$, mentoring $(17 \%)$, motivational talks $(5 \%)$ and competitions (4\%). It is important to note that most of the time these programs do not establish a clear difference among workshops and courses, they use both words indistinctly. The research only registers the name they used online to label the activity course or workshop. Many times, the detailed information about the activity like academic content, calendars or course/workshop length is insufficient. Only $60 \%$ of the programs visibly make the information about the length of the activities clear. Although $42 \%$ of programs advertised themselves as actions to promote the inclusion of women into STEM fields, only 14\% include activities to cover issues or topics in the four branches (Science, Technology, Engineering and Mathematics). In fact, $70 \%$ of all the sample is exclusively centered in providing computer programming activities. This divergence provides valuable information that will be discussed in the following section. The third and last category, "goals" (3) embraced variables related with the main goal or goals of these programs. Something important to highlight in this section is the fact that most of the programs blend specific academic objectives with social aims, for example "to provide the basic fundaments of computer programming", "to reduce the gender divide in STEM academic careers", or "to introduce role models and leadership to the girls." At least 35\% of the programs praise the approach of girls into science, particularly to coding, as a crucial action to promote women empowerment. However, it is likely to observed in these programs' goals, the same recurrent glitches observed in the traditional programs of this kind. They do not offer a clear explanation of reasoning of how learning to code will eventually supports women's empowerment. This issue will be discussed in the following section.

\section{DISCUSSION AND CONCLUSIONS}

The fieldwork's outcomes provided important information not only about the basic aspects of the actions to support the women inclusion in STEM, their objectives, the activities, who sponsors them and on which countries have more projects of this kind. Although the results also support some previous questionings that emerged from the analysis of existing literature: (1) In many cases, the programs marketed as STEM activities (Workshops/mentoring) but they only provide content related with information technologies, particularly computer programming. It is not the case that coding is not related with STEM, since it 
belongs to the technology field. However, science is more than learning the basics of computer programming or constructing robot toys, centering merely in this topic, and excluding math or astronomy activities, it gives the young girls a reductionist and unrealistic idea about STEM fields. (2) It is possible to observe how most of the programs do not publish on their website detailed information about the academic contents, education competences, didactic strategy, or even the schedule or the length of the activities. The absence of this information could mislead parents or teachers at the moment of selecting a program for their daughters or students. (3) Evidence from the fieldwork showed the little involvement of local governments and universities in these programs. This fact arouses important implications for the development of activities because they are elaborated by the NGO and companies without consulting official educative curricula or teacher organizations from the country in where the course or actions take place. Some events only take a day or two, making it impossible to make a report about the negative or positive effects of the workshops or talks. Most of the time, these efforts are lost because there is no continuity or a record of the final outcomes. (4) In addition, it is possible to observe the spread of a commodified model in where the most important target is to report a high number of enrollments or even to sell stock related to the program like books, toys or souvenirs. This overload of participants, as in the case of other modalities such as MOOCS course, cast doubts upon the imposition of an inflexible instructional model which does not take into account the particularity of every student, as in the case of migrants or racial minorities (Sengupta-Irving and Vossoughi, 2019). (5) Connected to last issue is the imposition of an aspirational stereotype model of scientific women. When studying the pictures and texts employed by some of NGO or companies to advertise their programs is possible to note a clear tendency to support a discourse that favors the individual accomplishment and economic success in detriment of collective goals. Here are some examples: "Girls who have programmed their own 'app', intend to reach Silicon Valley", "-My objective- is that more girls see our sector (IT) as a way for their social and economic empowerment", "They are empowering students to transform their lives and to participate in the digital revolution, which still feels so distant to many." In this setting, we agree with some critics who have pointed out how the visual imaginary and textual narrative used in these programs are focused mainly on fulfilling profitable objectives in neoliberal agendas (Chesky and Goldstein, 2018). Those aims do not necessarily coincide with social or community needs. Paradigmatic examples such as the case of Elizabeth Holmes, who was praised in media as the new Einstein and gave many talks about women empowerment, and her company Theranos are good recalls of the negative outcomes produced by the imposition of this neoliberal model without considering ethical and social concerns (The Economist, 2018). (6) While there is no doubt that these programs have enjoyed mediatic and attendant success, and in the case of some of them, great economic profits as well, there is no strong evidence or longitudinal studies to support their claims of social achievements, particularly regarding one of their main goals, to increase the presence of women in STEM (Mervis, 2018). When reading their statements on the Internet, it is possible to perceive the same re- 
38 current overestimation of the final outcomes of their actions, about 35\% make statements about how STEM and code workshops empower women, but most the time their reports are vague, and do not offer further evidence of this fact, particularly regarding the achievements in the long-run.

Besides the evidence against the possible positives outcomes of these programs, there are some arrangements that could improve their implementation (a) to pay more attention to the design of the activities, (b) to extent the content far beyond information technologies, to include activities related with other scientific fields. (c) It is important to pay attention to the singularities of the participants, particularly when dwelling with minorities such as migrants, (d) and to make alliance with universities and other actors to ensure the following and tracking of these actions in the long run. (e) The tribulations associated with the digital gender divide are more complex than just developing digital skills (learning to code) or providing IT infrastructure; it is mandatory to set enduring and integral actions to diminish their effects and avoid falling into a reductionist approach. And finally (f) women's empowerment is not an isolate task, but a cooperative process that requires the involvement of other actors like parents, teachers, practitioners and private and public organizations.

David Ramírez-Plascencia (david.ramirez@ redudg.udg.mx). Mexican professor (Guadalajara, Mexico; 1980). Doctor in Social Sciences from El Colegio de Jalisco. He is a researcher, instructor of subjects related to new information and communication technologies and their impact on society. He is a founding member of Paakat: Journal of Technology and

Rosa María Alonzo-González (ralonzo@ suv.udg.mx). PhD in social sciences, she is a member of the National System of Researchers Level C. (SNI, CONACYT), and she works at the University of Guadalajara, where she is doing a postdoctoral research at the Institute of Knowledge Management and Learning in
Society. He has published several articles on censorship in digital media, migration and social networks, and the impact of digital policies on social development. He is currently a member of the National System of Researchers (SNI) Level 1 and works as a researcher in the System of Virtual University of the University of Guadalajara.

Virtual Environments. Since 2011, she collaborates within the Agorante research group at the University of Colima whose research focuses on the use of digital technologies for social inclusion. Her research works have focused on the social uses of information and communication technologies (ICT). 


\section{References}

Abu-Shanab, E. and Al-Jamal, N. (2015). "Exploring the Gender Digital Divide in Jordan". Gender, Technology and Development, 19(1), pp. 91-113. <https://doi. org/10.1177/0971852414563201>.

Baumermann, C. and Kuchlmayr, F. (2019). "Frauen und Technik! Wie man Mädchen für die Naturwissenschaften gewinnt". Spiegel Online. Retrieved August 05, 2019 from $<$ https://bit.ly/31XQySe>.

Bendiek, S. (2017). "STEM-Studie: Wie wir noch mehr Mädchen für Technik begeistern". Retrieved August 5, 2019 from <https://bit. ly/2MFBqFi .

CEPAIM. (2015).Tekl@. Notas para el empoderamiento digital con mujeres. Murcia: CEPAIM.

Chesky, N. and Goldstein, R. A. (2018). "Packaging Girls for STEM or STEM for Girls? A Critique on the Perceived Crisis of Increasing Female Representation in STEM Education". Critical Education, 9(16), pp. 98-125.

Colnodo. (2006). Mujeres: Capacitar para empoderar. Colombia: APC.

Farmer, L. (2008). Teen Girls and Technology: What's the Problem, What's the Solution? New York: Teachers' College Press.

French, L.; Vega Montiel, A., and Padovani, C. (eds.) (2019). Gender, Media \& ICTs: New Approaches for Research, Education \& Training. Paris: UNESCO.

Gheyle, N. and Jacobs, T. (2017). Content Analysis: A Short Overview. Ghent: Centre for EU Studies, Ghent University.

Gordon, N. S. and Trammel, J. (2016). "Social Media, Women, and Empowerment: The Uses of Social Media Platforms by WNGOs in Jamaica and Brazil". Studies in Media and Communications, 12, pp. 93-130. <https://doi. org/10.1108/S2050-206020160000012006>.

Gray, T. J. Gainous, J. and Wagner, K. M. (2017). "Gender and the Digital Divide in Latin America". Social Science Quarterly, 98(1), pp. 326340. <https://doi.org/10.1111/ssqu.12270>.
Grupo de Trabajo 'Género y TIC'. (2010). "Informe sobre la participación del Grupo de Trabajo Género y TIC." Presented at the XI Conferencia Regional sobre la Mujer de América Latina y el Caribe. Brasilia, 13-16 July. Retrieved from <https://bit.ly/2zpsPya $>$.

Hafkin, N. and Taggart, N. (2001). Gender, Information Technology, and Developing Countries: Washington: USAID.

Holanda, M. [et al.]. (2017). "Percepção das meninas do ensino médio sobre o curso de computação no Distrito Federal do Brasil". Presented at the Congreso de la Mujer Latinoamericana en Computación (LAWCC-CLEI) - JAIIO 46. Córdoba, Argentina, September 4-8. Retrieved from <https://bit.ly/2KXjaoW>.

IWMF. (2011). Global Report on the Status of Women in the News Media. Washington: International Women's Media Fundación.

Júnior, W. [et al.]. (2019). "Techno Girls: Oficinas de programação de jogos para estudantes de escolas públicas". Anais do XIII Women in Information Technology. Belem, July 15-16.

Koch, J.; Polnick, B. and Irby, B. (2014). Girls and Women in STEM: A Never Ending Story. Charlotte, NC: Information Age Publishing.

Krippendorff, K. (2018). Content Analysis: An Introduction to Its Methodology. California: SAGE Publications.

Lovegrove, G. (1991). Women into Computing: Selected Papers, 1988-1990. New York: Springer Verlag.

Medeiros, C. B. (2005). "From Subject of Change to Agent of Change: Women and IT in Brazil". Proceedings of the International Symposium on Women and ICT: Creating Global Transformation. Baltimore, June 12-14.

Mervis, J. (2018). "They're Fun. But Can STEM Camps for Girls Really Make a Difference? Science" AAAS. Retrieved July 30, 2019 from <https://bit.ly/2MEu1Gj>.

Miller, L. [et al.]. (2000). "Saying 'Welcome' Is Not Enough: Women, Information Sys- 
tems and Equity in Work". Career Development International, 5 (7), pp. 379-389.

Minichiello, F. (2018). "Disciplines scientifiques et inégalités de genre: Une préoccupation mondiale". Revue Internationale d'Éducation de Sèvres, (79), pp. 14-17. <https:// doi.org/10.4000/ries.6787>.

Moghadam, V. M. (2010). "Global Gender Inequality and the Empowerment of Women: A Discussion of Half the Sky: Turning Oppression into Opportunity for Women Worldwide". Perspectives on Politics, 8(1), pp. 284-286. <https://doi.org/10.1017/ S1537592709992891>.

Montgomery, C. and Fernández-Cárdenas, J. M. (2018). “Teaching STEM Education Through Dialogue and Transformative Learning: Global Significance and Local Interactions in Mexico and the UK". Journal of Education for Teaching, 44(1), pp. 2-13.

Naciones Unidas. (1979). "Convención sobre la eliminación de todas las formas de discriminación contra la mujer". Retrieved July 29, 2019 from <https://bit.ly/2uysyqx>.

Naciones Unidas. (1995). Declaración y Plataforma de Acción de Beijing. Beijing: Naciones Unidas.

Nation, J. M. [et al.]. (2019). "Being and Becoming Scientists: Design-Based STEM Programming for Girls". Afterschool Matters, 29, pp. 36-44.

Nimmesgern, H. (2016). “Why Are Women Underrepresented in STEM Fields?" Chemistry - A European Journal, 22(11), pp. 3.529-3.530. <https://doi.org/10.1002/chem.201600035>.

OECD. (2000). Learning to Bridge the Digital Divide. Paris: Organisation for Economic Cooperation and Development (OECD).

-. (2015). Inequalities in Digital Proficiency: Bridging the Divide. Paris: Organization for Economic Co-operation and Development (OECD).

-. (2018). Bridging the Digital Gender Divide: Include, Upskill, Innovate. Paris: Organization for Economic Co-operation and Development (OECD).
-. (2019). Going Digital: Shaping Policies, Improving Lives. Paris: Organization for Economic Co-operation and Development (OECD).

Page, N. and Czuba, C. E. (1999). "Empowerment: What Is It?". Journal of Extension, 37(5).

Peral, B. P.; Gaitán, J. A., and Ramos, Á. F. V. (2015). "De la brecha digital a la brecha psico-digital: Mayores y redes sociales". Comunicar: Revista Científica de Comunicación y Educación, 23(45), pp. 57-64. <https://doi. org/10.3916/C45-2015-06>.

Rappaport, J. (1984). "Studies in Empowerment: Introduction to the Issue". In: J. Rappaport, C. Swift, and R. Hess (eds.). Studies in Empowerment: Steps Toward Understanding and Action. Philadelphia: Haworth Press, pp. 1-7.

Riffe, D.; Lacy, S., and Fico, F. (2013). Analyzing Media Messages: Using Quantitative Content Analysis in Research. New York: Routledge.

Rivest, J. (2015). “Éveiller l'intérêt des filles pour la technologie et l'ingénierie au regard de leurs representations". Retrieved August 05, 2019 from <https://bit.ly/2NvCYl3>.

Rogan, A. I. and de Kock, D. M. (2005). "Chronicles from the Classroom: Making Sense of the Methodology and Methods of Narrative Analysis". Qualitative Inquiry, 11(4), pp. 628-649. <https://doi. org/10.1177/1077800405276777>.

Rogers, E. M. (2001). "The Digital Divide". Convergence, 7(4), pp. 96-111. <https://doi.org /10.1177/135485650100700406>.

Roudi-Fahimi, F. and M. Moghadam, V. (2003). "Empowering Women, Developing Society: Female Education in the Middle East and North Africa". Retrieved July 29, 2019 from <https://bit.ly/2HzlDys $>$.

Sanabria-Z, J. and Romero, M. (2019). L'écosystème techno-créatif de la Métropole Nice Côte d'Azur. Des acteurs et des tiers lieux pour le développement d'une citoyenneté créative et d'une éducation aux compétences transversales. Quebec, Canada: Livres en ligne du CRIRES. 
Sengupta-Irving, T. and Vossoughi, S. (2019). "Not in Their Name: Re-interpreting Discourses of STEM Learning Through the Subjective Experiences of Minoritized Girls". Race Ethnicity and Education, 22(4), pp. 479-501. <https:// doi.org/10.1080/13613324.2019.1592835>.

Shewmaker, J. W. and Lee, S. K. (2015). "Distributed Leadership in a UniversitySchool Collaborative Partnership to Build the STEM Pipeline for Girls". Innovations in Higher Education Teaching and Learning, 5, pp. 195-209. <https://doi.org/10.1108/S2055364120150000005011>.

The Economist. (2018). "The Rise and Fall of Elizabeth Holmes, Silicon Valley's Startup Queen". The Economist. Retrieved Julio 30, 2019 from <https://econ.st/2MDyNnD>.

- . (2019). "The Second Half of Humanity Is Joining the Internet". The Economist. Retrieved June 11, 2019 from <https://econ. st/2QWSoyn $>$.

UNESCO. (2003). Bridging the Digital Divide. Paris: UNESCO.

-. (2012). Indicadores de género para medios de comunicación: Marco de indicadores para evaluar la sensibilidad en materia de género en las operaciones y contenidos mediáticos. Paris: UNESCO.

-. (2018a). Cracking the Code: Empowering Rural Women and Girls Through Digital Skills; Side Event During the 62nd Session of the Commission on the Status of Women, 14 March 2018, United Nations Headquarters: Report. New York: UNESCO.

—. (2018b). Women in Science. Paris: UNESCO.

—. (2018c). "Les filles peuvent coder: Le programme Information pour tous de l'UNESCO lance un nouveau projet au Ghana". Retrieved August 5, 2019 from <https:// bit.ly/2HgoQWZ>.
-. (2019). Descifrar el código: La educación de las niñas y las mujeres en ciencias, tecnología, ingeniería y matemáticas (STEM). Paris: UNESCO Publishing.

United Nations. (2018). "Speakers Highlight National Strategies to End Gender Divide in Media, Digital Decision-Making, As Women's Commission Continues Sessions [United Nations Official Site]". Retrieved July 29, 2019 from <https://bit.ly/2MEN2s6>.

Vega-Montiel, A. and Macharia, S. (2019). Setting the Gender Agenda for Communication Policy: New Proposals from the Global Alliance on Media and Gender. Paris: UNESCO.

WACC. (2015). Global Media Monitoring Project (GMMP) 2015. Toronto: Asociación Mundial para la Comunicación Cristiana (WACC).

Whynot, J. [et al.]. (2019). "Knitting Theory in STEM Performance Stories: Experiences in Developing a Performance Framework". Canadian Journal of Program Evaluation, 33(3), pp. 354-374.

World Wide Web Foundation. (2014). "ICTs for Empowerment of Women and Girls: A Research and Policy Advocacy Initiative on Empowering Women on and Through the Web in 10 Countries". Retrieved July 29, 2019 <https:// bit.ly/2NylR23>.

Youance, S. and Groleau, A. (2018). " $\mathrm{Fa}$ ciliter l'accès des filles aux programmes universitaires en STIM: Les cas du Québec et d'Haïti". Retrieved August 05, 2019 from <https://bit. ly/325Tvjy>.

Zimmerman, M. A. (2000). "Empowerment Theory: Psychological, Organizational, and Community Levels of Analysis". In: J. Rappaport, Seidman, E. (eds.). Handbook of Community Psychology. New York: Springer, pp. 43-63. 
